\title{
A OBJETIVIDADE NA BUSCA PELO BEM SUPREMO: UMA CARACTERÍSTICA DO BOM ALUNO DA ÉTICA NICOMAQUEIA $(E N)^{1,2}$
}

\author{
Priscilla Tesch Spinelli (UFRGS) ${ }^{3}$ \\ ptspinelli@gmail.com
}

Resumo: Este artigo busca mostrar como podemos pensar o a priori histórico sob duas perspectivas diferentes. Por um lado, quando Husserl fala de um a priori histórico, ele se refere à tradição - uma forma de afirmar que a história do pensamento é contínua e segue um espírito em comum. Isto implica, ao mesmo tempo, que a tradição, apesar de ser um discurso anterior ao sujeito, depende, claramente, de um sujeito falante, de sua atividade presente, para que ela possa existir. Por outro, na proposta de Foucault, o a priori histórico é visto a partir daquilo que tornaria possível surgir uma multiplicidade de enunciados numa dada época (arquivo). Portanto, trata-se de uma história que não está pautada na subjetividade, mas no próprio discurso. O que resta destas duas concepções é saber o estatuto das ciências matemática e física: seriam elas um modelo ou uma exceção?

Palavras-chave: Objetividade; Ética; Aristóteles; Virtude Moral.

\section{INTRODUÇÃO: A FINALIDADE COM QUE SE INVESTIGA}

No livro I da República, o qual busca esclarecer a natureza da justiça, Trasímaco afirma que a injustiça, e não a justiça, é virtude (PLATÃO, 2000, 348e). Diante dessa afirmação, Sócrates de certa forma paraliza. Até então, Trasímaco havia afirmado que "nos damos bem", "tiramos vantagens"

\footnotetext{
1 Recebido: 29-09-2014/Aprovado: 21-01-2015/Publicado on-line: 17-02-2015.

$2 \mathrm{O}$ texto que segue é fruto de pesquisa que recebeu apoio da FAPERGS - Edital ARD 03/2012.

3 Priscilla Tesch Spinelli é Professora Adjunta da Universidade Federal do Rio Grande do Sul, Porto Alegre, RS, Brasil.
} 
ou obtemos benefícios aos sermos injustos, e isso sobretudo quando não somos pegos, mas deixara intocado o pressuposto de que a injustiça é um vício e, portanto, algo mau, vergonhoso e censurável. Ao pretender que é por ser uma virtude que a injustiça nos beneficia, Trasímaco abala esse pressuposto: a injustiça vem a ser algo bom, digno de orgulho e elogiável. Trasímaco está consciente desse pressuposto; ele sabe que, para Sócrates e os demais presentes, 'virtude' é a palavra usada para designar uma disposição que nos beneficia, recomendando assim a sua busca e desenvolvimento. A identificação da injustiça como virtude é marcada por Sócrates como certo impedimento para o prosseguimento da argumentação, pelo menos do modo como estava sendo conduzida. "Isso é uma posição ainda mais irredutível, companheiro, e já não é fácil arranjar maneira de a refutar", afirma ele (PLATÃO 2000, 348e).

Ao não reconhecer como vergonhosa a injustiça e como valiosa e bela a justiça, Sócrates faz com que Trasímaco admita uma outra coisa: que ele não está disposto a envolver-se na discussão dialética para descobrir o que é a justiça ou como podemos ser felizes, mas para vencer a argumentação. Afirma Sócrates: "Contudo - retorqui - não devemos recuar na prosecução do exame, enquanto eu supuser que estás a dizer o que pensas. Pois me parece, ó Trasímaco, que realmente não estás a zombar agora, mas a dizer o que julgas ser a verdade" (meus itálicos), ao que Trasímaco reage: "Que diferença te faz se é o que eu penso ou não, desde que não refutes a minha argumentação?" (meu itálico) "Nenhuma", responde Sócrates, com o que ele certamente gostaria de dizer "Para mim nenhuma, mas em relação ao que supostamente estávamos fazendo, toda!"(cf. 
PLATÃO 2000, 348e-349a). Esse momento do diálogo faz emergir um requisito anterior à discussão: que ao discutir ou examinar algo os interlocutores tenham o mesmo objetivo em vista. Se o objetivo de Trasímaco é vencer a argumentação, ao perceber algum pressuposto do qual a investigação parte - no caso, que a virtude é bela e boa e o vício é mau e vergonhoso -, ele estará disposto a recusar tais pressupostos, não admitirá a verdade, pois isso significará que foi vencido.

O Trasímaco da República representa um tipo extremo, alguém cujos interesses são admitidamente outros que os da discussão levada a cabo por Sócrates. Com efeito, para desvendar a natureza da justiça, da felicidade ou do que quer que seja, pretender vencer a argumentação, pura e simplesmente, não parece ser um bom caminho. A meu ver, Platão defende isso na medida em que a argumentação contra Trasímaco dá lugar, na República, a uma conversa entre personagens "que se entendem" acerca de pressupostos bastante fundamentais da discussão, dentre eles, não só que a justiça é virtude e a injustiça é vício mas também e sobretudo o objetivo em vista do qual discutem ${ }^{4}$.

\footnotetext{
4 Dois artigos de Roberto Bolzani (um deles ainda não publicado) são bastante esclarecedores acerca do papel de Trasímaco no livro I da República. O primeiro ("A retomada da tese de Trasímaco no segundo livro de A República", no prelo) considera a roupagem nova com que, no livro II, os irmãos Glauco e Adimanto vestem a tese defendida por Trasímaco no livro I, a saber, que a justiça é o interesse ou conveniência do mais forte e que, consequentemente, é melhor ser injusto do que justo - do que Glauco afirma explicitamente discordar (PLATÃO 2000, 358c). Um elemento crucial que impede o desenvolvimento do argumento é a rudeza e a agressividade com as quais Trasímaco discute com alguém que discorda dele (ele entra na discussão avançando sobre os demais, "como se fosse uma fera”, PLATÃO 2000, 336b5), não permite que o argumento se desenvolva. Uma mudança de atitude do interlocutor é requerida para que o argumento possa avançar. No segundo artigo ("Glauco, guardião do lógos"), Bolzani apresenta as qualidades sobretudo de Glauco ao exigir de Sócrates uma demonstração da justiça pelo que ela é nela mesma. A interpretação que avanço sobre o bom aluno da EN de Aristóteles se aproxima bastante da que Bolzani oferece acerca do "temperamento e visão de mundo adequados ao filosofar" de Glauco e Adimanto para ouvir a construção da cidade ideal na República. Agradeço imensamente a Bolzani pela gentileza e rapidez com as quais disponibilizou a mim seus textos, sobretudo o Cont.
} 
A atenção que Platão dedica à educação no restante da República revela algo importante: se a alma não for previamente preparada, uma investigação sobre o Bem dificilmente surtirá algum efeito, principalmente se o interloculor não tiver como objetivo esclarecê-lo. Penso que essa lição foi retida por Aristóteles e apresentada por ele na exigência do bom aluno da $E N^{5}$. Aristóteles não é, infelizmente, muito explícito ao apresentar o conteúdo dessa exigência. É para um elemento desse conteúdo que quero, aqui, chamar a atenção: o compromisso com a objetividade da investigação.

O que entendo com a expressão grifada acima pode ficar mais claro a partir do seguinte. A principal pergunta que a EN busca responder é "qual a melhor vida para um ser humano levar?" ou, usando termos aristotélicos mais explícitos, "o que é o bem supremo para o ser humano?". Aquele que há de realizar adequadamente a investigação proposta pela EN aceita essa pergunta como relevante e passível de ser corretamente respondida ${ }^{6}$. Aceitar isso implica comprometer-se com a busca por uma única resposta para ela. Isso significa aceitar que essa resposta é válida para todos, inclusive - ou talvez, especialmente - para si próprio. Significa, ainda, compreendê-la como inevitável ou irremediavelmente verdadeira e válida para todos os seres humanos enquanto tais, quer eles sejam capazes de reconhecer isso ou não. É com isso que se está comprometido ao aceitar buscar uma resposta à principal

primeiro, ainda não publicado.

5 Cf. EN I 3 1094b27-1095a11 e 4 1095b4-14 (esses trechos serão apresentados e discutidos a seguir). Cf também o final da EN (X 9 1179b3-19).

6 Talvez seja preciso aceitar mais coisas, como a ideia de que a filosofia é capaz de apresentar uma resposta substancial - ainda que ampla e em linhas gerais - a essa pergunta. 
pergunta colocada pela EN.

Abordarei o comprometimento com a objetividade a partir das razões que Arisóteles oferece para afirmar que é preciso ter sido educado nos bons hábitos para se beneficiar da investigação presente na EN. Aqueles que estão comprometidos com a objetividade da investigação ética são capazes de identificar correta e previamente estas coisas como sendo as virtudes, estas outras como sendo vícios, ainda que não estejam totalmente de acordo sobre o que cada uma dessas coisas é e qual seu papel em uma vida feliz. Trata-se, assim, de uma condição prévia: é preciso, antes de adentrar uma investigação sobre o bem humano, já saber identificar corretamente aquelas qualidades humanas que são verdadeiramente valiosas, aqueles traços de caráter verdadeiramente dignos de serem buscados e que contribuem, de uma forma que seré melhor explicada em tal investigação, para a felicidade.

Conforme veremos, aceitar o pressuposto de que há algo a ser dito de verdadeiro, universal e necessário sobre a vida boa para o ser humano implica que, ao realizar a investigação sobre essa vida, se esteja buscando algo com essas características. Apontar para a necessidade de buscar a verdade na investigação sobre o bem humano pode parecer tolo - quem investiria o seu tempo em uma investigação se não fosse para tentar encontrar a verdade? -; no entanto, em se tratando da busca por uma maior especificação da boa vida, pelo maior bem para o ser humano, não é. Este é talvez o assunto em relação ao qual nossas crenças e convicções pessoais parecem falar mais alto. $\mathrm{O}$ simples fato de serem nossas crenças sobre o que é bom - e sobre o que é bom para nós - faz com que tenhamos a elas um apego maior, sejam ou não verdadeiras. Todos nos julgamos bom 
juízes do nosso próprio bem, da nossa própria vida: quem teria o direito de alegar ser mais expert na minha vida do que eu mesma?

Ora, a investigação aristotélica do bem supremo pretende nos ensinar algo sobre o nosso próprio bem. $\mathrm{O}$ que ela requer, assim como qualquer outra investigação, é que o acordo e o assentimento sejam dados sempre à tese que se mostrar verdadeira ou correta em virtude dos melhores argumentos, não sendo admissível que discordemos de uma posição ou rejeitemos uma ideia simplesmente porque ela contraria as nossas convicções prévias. É por isso que, no caso da investigação sobre o bem, o estudante precisa ter sido educado na virtude, amando-a por ela mesma, compreendendo-a como um valor digno de busca. Acerca disso, uma objeção pode ser apresentada: a educação na virtude que o estudante da EN deve ter para seguir com proveito sua investigação parece introduzir a convicção prévia que recém afirmei como algo que é preciso descartar. Buscarei responder a isso na sequência do texto.

\section{O BOM ALUNO E A EDUCAÇÃO NA VIRTUDE}

É fato conhecido até mesmo do leitor iniciante da EN que Aristóteles faz uma restrição acerca de quem é capaz de seguir de modo proveitoso a investigação sobre o bem humano, o que caracteriza aquele que se costumou chamar de "o bom aluno". Não é uma tarefa fácil ou simples determinar com precisão todas as características que este último deve apresentar. Mas creio que algumas coisas importante e determinantes são possíveis de estabelecer sobre isso. Os dois trechos do início da EN em que ocorre a 


\section{caracterização do bom aluno são os seguintes:}

(a) (...) um jovem não é um bom ouvinte das lições de ciência política, pois é inexperiente quanto às ações que ocorrem na vida, mas as discussões [políticas] partem delas e são sobre elas; além disso, uma vez que ele [o jovem] tende a seguir as suas paixões, o estudo será vão e improfícuo, pois o fim visado não é o conhecimento mas a ação. E não faz diferença se ele é jovem na idade ou no caráter; o defeito não depende do tempo, mas do seu modo de vida, ao perseguir um a um os objetos conforme a paixão os apresenta. Para tais pessoas, assim como para o incontinente, o conhecimento não será profícuo; mas para aqueles que desejam e agem de acordo com o princípio racional o conhecimento de tais assuntos trará grande benefício (EN I 3 1095a2-11, grifos meus)?

(b) (...) aquele que há de ouvir de maneira adequada as lições sobre o que é nobre e justo e, em geral, sobre ciência política, deve ter sido educado nos bons hábitos. Pois o 'que' é um princípio e se isto estiver suficientemente claro, ele não precisará do 'porquê'; e o homem que foi bem educado possui ou pode facilmente possuir os princípios (EN I 4 1095b4-8, grifos meus). ${ }^{8}$

Segundo (a), o jovem será excluído como um bom ouvinte destas lições precisamente porque (a1) é inexperiente nas ações. A observação feita na sequência da passagem apresenta mais uma razão para acreditar que ele não será um bom aluno: ele é (a2) imaturo quanto ao caráter, o que se mostra pelo fato de perseguir "um a um os objetos conforme a paixão os apresenta”. Já (b) afirma que para ouvir de maneira adequada as lições sobre o que é nobre e justo é preciso ter sido educado nos bons hábitos. Mas em que

\footnotetext{
7 Transcrevo versões minhas para o português da versão inglesa de David Ross do texto da EN. Qualquer alteração da versão inglesa será indicada em nota e justificada.

8 Traduzi o termo arché nesse trecho por 'princípio', diferentemente de Ross, que usa "startingpoint" ("ponto de partida"). Na linha 1095a35 o termo já aparece e Ross o traduz por "principle" ("princípio"). Prefiro usar um mesmo termo ("princípio") e deixar em aberto a questão de tomar arché como ponto de partida de uma investigação ("starting-point") ou de chegada ("principle"), entendendo essa como uma questão de interpretação.
} 
consiste tal boa educação? O que Aristóteles nos diz é que os bem educados são os que possuem ou podem facilmente possuir os princípios da investigação que se inicia. A primeira frase de $(b)$ pode ser vista como um esclarecimento ou especificação das características presentes em (a1) e (a2): é a experiência nas boas ações - a educação nos bons hábitos - o que é necessário para seguir com proveito as lições políticas, a qual pode ser atribuída àqueles que "desejam e agem de acordo com o princípio racional", conforme é afirmado no final de (a). Se, conforme Aristóteles afirmou em (a), o objetivo final dessa investigação é a ação e não apenas o conhecimento que ela proporciona, então ela não será proveitosa para aqueles que seguem uma a uma as suas paixões ou são incontinentes. Ora, os primeiros buscam, via de regra ou como uma tendência, apenas a satisfação dos seus desejos, não considerando se isso é de fato bom, nobre ou correto, se é isso mesmo o que devem fazer. Já os segundos até consideram adequadamente o que devem fazer e se importam com isso, mas acabam "cedendo" e realizando a ação contrária. $\mathrm{O}$ conhecimento proporcionado pela investigação ética, para tais pessoas, será inútil.

Restringir o bom aproveitamento da investigação do bem supremo aos experientes nas boas ações, excluindo assim os jovens, imaturos de caráter e incontinentes, pode dar origem a uma série de perguntas: por que mesmo esse estudo não será capaz de beneficiar aqueles que aparentemente mais precisam dele, a saber, os inexperientes, incontinentes e, principalmente, os "mal educados", ou seja, os que seguem uma a uma as suas 
paixões? ${ }^{9}$ Tal estudo não deveria oferecer argumentos que visassem orientar ou convencer essas pessoas a mudar de vida? Se a felicidade é o maior dos bens para o ser humano, e a vida ativa virtuosa é a melhor para todos, a teoria ética não acaba tendo alcance regional com essa restrição? Com efeito, ela não seria uma espécie de pregação aos já convertidos, uma vez que os beneficiados por ela já "desejam e agem de acordo com o princípio racional"? Não seria necessário que a teoria moral se apoiasse em fatos universais e inegáveis de todo ser humano, o que a autorizaria a se impor a todos de maneira indiscutível, a despeito das suas disposições e experiências prévias?

Creio ser correto dizer que Aristóteles tinha pretensões universais e abrangentes ao conceber a EN. É verdadeiro dizer que ele pretendia fornecer uma resposta definitiva, necessária e universal à questão "como devemos viver?" ou "qual a melhor vida para um ser humano levar?"10. Trata-se

\footnotetext{
9 Essa questão foi colocada explicitamente, por exemplo, por Bernard Williams. Comparando com e distinguindo da perspectiva adotada por Sócrates e/ou Platão nos diálogos platônicos, ele afirma que, uma vez que Aristóteles não pensa que as lições presentes na EN possam constituir substancialmente os raciocínios deliberativos daquele que a estuda, a investigação ética "não dirige mais as suas considerações a cada pessoa, de tal forma que cada uma pudesse responder à questão socrática. Voltamos assim a um ponto visto anteriormente, que a resposta para o cético [aquele que perguntaria: por que eu devo agir moralmente?] seria em primeiro lugar benéfica para nós. Aristóteles de fato não está interessado no ceticismo sobre a vida ética, e esta é uma das muitas diferenças que saltam aos olhos entre o seu mundo e aquele de Sócrates e Platão. Ele está interessado simplesmente nos homens que têm os valores errados ou um mau caráter. Mas o ponto é o mesmo: a resposta à questão socrática não pode ser usada por aqueles que (da perspectiva do restante das pessoas) mais precisam dela" (Cf. WILLIAMS 1985, 39-40).

10 Devemos notar que há uma tensão entre essa afirmação e a ressalva feita por Aristóteles acerca da exatidão apropriada a ser buscada na investigação ética (cf. EN I 3 1094b12-14; 1094b19-26; I 7 1098a21-32; I 13 1102a23-25 etc.). Uma das formas de entender essa ressalva seria justamente recusar que possamos ter conhecimento ético universal e necessário, devendo contentarmo-nos com afirmações verdadeiras, apenas, "nas mais das vezes" (cf. 1094b19-22). Pensamos que a referida tensão poderia ser resolvida caso "modalizássemos" a universalidade e a necessidade que se pode pretender em Ética: certamente não se trata do mesmo tipo de universalidade e necessidade que as que podemos encontrar na Matemática, por exemplo. Ainda assim, ao buscar pelo esclarecimento do Bem Supremo, tais coisas são almejadas e podem ser alcançadas dentro das possibilidades que oferecem o assunto em questão. De fato, algumas coisas sobre a boa vida só Cont.
} 
da questão socrática, aquela que Sócrates buscava responder nos diálogos de Platão. Com efeito, até hoje julgamos que é possível aprender com Aristóteles - e também com o Sócrates de Platão, vale a pena assinalar - acerca desse assunto. Essa é uma das razões pelas quais a acusação de um regionalismo da teoria ética devido à restrição a um certo público incomoda não só o intérprete e estudioso de Aristóteles, mas aquele que quer pensar sobre Ética e e as questões que envolvem a boa vida, de um modo geral. $\mathrm{O}$ que essa restrição da audiência significa e que consequências elas traz para a acusação de um regionalismo na ética aristotélica?

A resposta que quero desenvolver à questão acima foi sugerida por Richard Kraut em dois artigos ${ }^{11}$. A restrição significa a exigência que os alunos da $E N$ avaliem a teoria ética que está sendo apresentada da maneira mais livre e aberta possível, que esses alunos permitam que os argumentos se desenvolvam e os levem às conclusões que deles se seguirem de modo, por assim dizer, não afetado. Isso não significa que a teoria não é válida para todo ser humano; ela é, mas não poderá ser reconhecida como tal por todos. Por outro lado, ao dizer que o aluno precisa enfrentar tal teoria de maneira não afetada não estou defendendo que ele deva ser alheio, neutro ou indiferente à teoria que avança. Ao dizer isso, pretendo defender que o

podem ser ditas com verdade "nas mais das vezes"; outras, não. Não é nas mais das vezes que a eudaimonia é atividade da alma segundo perfeita virtude, por exemplo, mas sempre e necessariamente. Com efeito, tal afirmação parece ter sido extraída do argumento da função própria como algo de universal e necessário acerca do que é o nosso bem. A partir disso, a questão que se põe é acerca do modo como tal argumento sustenta essa afirmação. Isso, no entanto, deverá ser examinado em outro momento.

11 "Como justificar proposições éticas: o método de Aristóteles" (KRAUT 2009) e "Aristotle on Method and Moral Education" (KRAUT 1998). 
aluno deve ser capaz de avaliar corretamente as premissas e os argumentos apresentados e, na medida em que os reconhece como bons e corretos, ser capaz de adotar para si as suas conclusões. Isso significa também que ele é capaz de colocar à prova, avaliar e reconsiderar as suas próprias convicções e o seu modo de vida, desde que boas razões sejam apresentadas para tanto.

Antes de prosseguir, gostaria de fazer uma observação. Defender que o bom aluno da investigação ética deve ser capaz de adotar para si as conclusões às quais ela chegar não significa sustentar que Aristóteles pensava que a influência da teoria ética no modo de vida de alguém era direta e imediata, sendo possível "aplicar" ou "colocar em prática" as coisas que ali são ditas. Mas podemos afirmar que ele esperava, sim, uma influência dessa teoria na ação pelo menos de modo indireto, mediado pela reflexão. A teoria ética aristotélica ajuda a promover a reflexão do agente acerca das suas próprias escolhas, valores, interesses, objetivos e estratégias para alcançá-los. Ela pretende direcionar e motivar as considerações do agente no sentido correto, a saber, o da virtude. Se é assim, uma pessoa cujo temperamento se reduz a seguir uma a uma as suas paixões (ou a não ser capaz de se ater àquilo que deliberadamente elege), dificilmente fará esse tipo de reflexão, não se dispondo a rever e reavaliar as suas atitudes e as razões de que dispõe para agir assim (o incontinente pode até fazer isso, mas não terá efeito algum sobre seu modo de viver, como não têm efeito as concepções práticas corretas que ele já possui). É isso o que significa dizer que para tais pessoas o estudo do bem humano será inútil ${ }^{12}$.

12 Se considerarmos que a teoria ética aristotélica não é constitutiva de virtude moral, Cont. 
O temperamento em razão do qual seguimos uma a uma as paixões, o qual pode ser qualificado como propenso ao vício ${ }^{13}$, torna-nos tendenciosos na nossa avaliação de argumentos morais e considerações éticas ${ }^{14}$. Com efeito, não é preciso ser vicioso - ou adotar uma posição "irredutível”, como a de Trasímaco no livro I da República para não tirar proveito da investigação sobre o bem humano: basta ser moralmente imaturo ou muito jovem. Durante uma discussão sobre como agir, qual o melhor modo de viver etc., alguém que conduz a sua vida visando

poderíamos nos perguntar se alguém já virtuoso seria um "bom aluno" da Ética Nicomaqueia. Creio que a isso deveríamos responder que sim. Embora, ao menos em princípio, tal estudante não tivesse nada a aprender do ponto de vista estritamente prático ou moral - pois, supostamente, ele já sabe tudo o que deveria saber nesse assunto -, ele teria muito a aprender do ponto de vista conceitual ou filosófico. O estudo de ética não o tornaria uma pessoa melhor - ao menos não diretamente -e, nesse sentido, seria inútil para ele. Mas é preciso notar que o estudo de ética seria inútil para o virtuoso não por ele ser incapaz de tirar um proveito prático do mesmo, mas por ele já ter como que ultrapassado essa fase. Inutilidade, no entanto, não significa total ausência de benefício: ele ainda pode, através da Ética, conhecer melhor a origem das suas crenças e valores. Entretanto, não devemos deixar de notar que, ainda que para o virtuoso estudar ética seja "pregar para um convertido", suas crenças e valores tendem a se fortalecer e fixar se ele tiver maior clareza dos princípios que os fundamentam (e fornecer os princípios é também uma boa descrição do que ocorre na investigação ética, como indicarei no final deste texto).

13 Chamo-o de propenso ao vício e não de vicioso porque aquele que segue uma a uma as suas paixões, buscando unicamente satisfazer os seus desejos, pode não fazê-lo deliberadamente e não é, por isso, censurável como o vicioso, sobretudo se é ainda bastante jovem. As crianças pequenas e os muito jovens ainda não são capazes de ou não aprenderam a considerar outra coisa ao buscar realizar seus desejos a não ser o prazer imediato que podem obter ou a dor imediata da qual podem escapar. No entanto, ninguém censuraria uma criança ou alguém muito jovem por "conduzir" assim a sua vida; antes, isso seria visto como natural ou próprio da idade; eles não buscam o prazer ou fogem da dor refletidamente ou por escolha deliberada, algo que o vicioso faz. Por outro lado, se continuarem a agir assim, se seus sentimentos não forem educados e eles não aprenderem a levar outras coisas em consideração - por exemplo, que para obter o que desejam não estão autorizados, em qualquer caso, a prejudicar outras pessoas -, provavelmente se tornarão viciosas. Essas pessoas virão, no final desse processo, a escolher deliberadamente o prazer, não se importando com tudo o mais de mau que isso possa causar, seja para os outros, seja para si, o que é característico de alguém vicioso.

14 Essa ideia pode ser encontrada n final do capítulo 5 do livro VI da EN: "Pois não é todo e qualquer juízo que os objetos prazerosos e penosos destróem e pervertem - por exemplo, o juízo que o triângulo tem ou não seus ângulos iguais a dois ângulos retos -, mas apenas aqueles juízos acerca do que deve ser feito." (1140b13-15) De uma perspectiva geral, a investigação ética trata daquilo que deve ser feito, razão pela qual a busca pelos objetos prazerosos e a fuga dos dolorosos influenciam negativamente os juízos daquele que seguirá tal investigação. 
os prazeres e fugindo das dores, por escolha deliberada ou não, dificilmente se posicionará de forma crítica diante das suas próprias concepções e crenças. Um bom argumento contrário a algo em que ele acredita, segundo o que conduz a sua vida, dificilmente fará com que ele mude de ideia. Devido ao seu modo de vida e ao modo como encara as suas próprias opiniões, dificilmente ele será persuadido por bons argumentos. Já a boa educação mantém aquilo que podemos chamar de "mente aberta", permitindo que o agente julgue livremente acerca daquilo que se apresenta a ele. Alguém que não foi bem educado, segundo Kraut,

(...) pode teimosamente insistir que ele está certo e recusar-se a repensar a questão de mente aberta. Pode ainda ser o caso que a sua experiência seja muito limitada e ele resista em reconhecer isso. Pode ainda ocorrer que ele careça da perspicácia necessária para reconhecer um ponto de vista superior ao seu. Alguém que usa um termo que é dito de muitas maneiras pode falhar em reconhecer a ambiguidade, mesmo depois de ela ter sido mostrada (KRAUT 2009, 84, grifos meus).

A atitude de resistência em aceitar argumentos mencionada por Kraut talvez ocorra menos ou seja menos influente em discussões mais teóricas e abstratas, como a prova do teorema de Pitágoras, da realidade do movimento ou o argumento do terceiro homem, dado que em tais assuntos "o que somos" parece estar menos em questão. Quanto a argumentos relacionados ao modo como devemos viver, que prescrevem este modo de vida como desejável e melhor e aqueles outros como evitáveis e piores, isso não é assim. Em tais assuntos, dificilmente deixaremos de nos envolver quando os consideramos, pois nos dizem respeito diretamente. E, dependendo do modo como até então vivemos a nossa vida e a defendemos, nos inclinamos a aceitar ou rejeitar argumentos que a ela se referem, o que 
pode comprometer o conteúdo das nossas considerações nas discussões. Se seguimos uma vida exclusivamente dedicada à satisfação dos nossos prazeres, dificilmente vamos querer ouvir ou dar crédito ao argumento que busca mostrar que nem todo prazer é bom e que alguns devem ser evitados (ou devem ser evitados até certo ponto, em certas circunstâncias etc.). Podemos querer evitar a verdade porque ela contraria nossas convicções e sentimentos, o nosso modo de vida, seja ele já deliberadamente perseguido ou não. Não estaremos, assim, abertos a descobrir, a desvendar a verdade e, possivelmente, vir a corrigir nossas opiniões, ideias e concepções.

É por essa razão que é preciso ter sido educado em bons hábitos, ter uma vida já parcialmente virtuosa ou direcionada à virtude, ao que é realmente bom, a fim de considerar apropriadamente argumentos que visem justificar e esclarecer isso que é realmente bom. Tais pessoas, buscando levar uma vida realmente boa, têm interesse em buscar uma teoria ética através da qual poderão não apenas encontrar razões filosóficas para continuar a viver a sua vida mas também e principalmente esclarecer melhor o lugar e a importância de cada um dos bens que a constituem, corrigindo sua concepção quando necessário. Aqueles que foram mal educados ou são muito imaturos, explica Kraut, "não têm interesse na tarefa intelectual difícil de desenvolver concepções sistemáticas de bondade, caráter, amizade, prazer e o resto da filosofia prática” (KRAUT 1998, 290). Tais pessoas buscariam a teoria ética apenas na medida em que ela os assegurasse dos seus (pré)conceitos, estes de que já dispõem, e não na medida em que eventualmente poderiam revisá-los, questioná-los, trocá-los por outros, colocando assim à prova 
algumas concepções que antes tomavam irrefletidamente como corretas. Como explica Kraut,

Aristóteles pensa que quando as pessoas desenvolvem maus hábitos, elas também desenvolvem certa atitude em relação ao raciocínio, a saber, entendem que a sua função é a de um instrumento para a satisfação dos seus próprios apetites e paixões. De tal forma que, ainda que ouçam os argumentos sobre os fins apropriados da vida, fazem isso como um esporte, e não consideram seriamente a possibilidade que a razão possa descobrir que alguns fins são mais valiosos do que outros. Seus hábitos assim garantem que elas nunca reavaliarão seriamente o valor dos seus fins. Em contraste com isso, aqueles que foram bem educados foram treinados a considerar a razão não como um mero instrumento a ser usado para outros propósitos, mas como algo valioso em si mesmo (KRAUT 1998, 286) (grifos meus).

Apesar de ser um pouco exagerado dizer que os maus hábitos de algumas pessoas "garantem que elas nunca reavaliarão seriamente o valor dos seus fins", penso que a dificuldade geral em que elas estão envolvidas foi corretamente assinalada por Kraut. Aquele que vê na razão apenas um instrumento para a satisfação dos seus desejos, quaisquer que eles sejam, não vê muito sentido em uma investigação sobre o bem humano, engajando-se nela, se isso ocorrer, como uma espécie de "esporte". Esse último pode ser entendido como o mero exercício argumentativo, apartado da ideia de buscar a verdade acerca de algo, de buscar esclarecer o que quer que seja. Sendo a discussão um jogo, uma disputa, busca-se apenas sair ganhando. Essa parece ser uma boa descrição da atitude de Trasímaco, como vimos. 


\section{RESOLVENDO UMA DIFICULDADE: A CONVICÇÃO PRÉVIA DO BEM EDUCADO}

Entretanto, alguém poderia alegar que o bem educado também tem os seus sentimentos e convicções e que, devido a isso, também está sujeito a avaliar argumentos sobre a boa vida segundo as inclinações oriundas dos seus hábitos. Portanto, também ele avaliará de modo parcial ou pessoal os argumentos. De fato, afirmei anteriormente que, em relação às questões sobre a boa vida, dificilmente as consideramos sem nos envolvermos. É preciso, no entanto, apontar para o que falta naquele que foi mal educado: ele não tem compromisso com a objetividade da investigação, com a busca pela verdade como algo valioso. Não é o envolvimento ou a ausência dele o que caracteriza a boa educação e, assim, o bom aluno das lições da EN. O mal educado não leva em conta a possibilidade de revisão das suas crenças, em relação ao que é preciso honestidade e talvez humildade para reconhecer que, sim, em certos aspectos ele estava errado, mas pretende se corrigir, quer não mais errar. Aquele que foi bem educado não é, ainda, virtuoso, mas quer melhorar. Querer melhorar pressupõe conceber algo como bom, certo ápice, parâmetro ou meta final independente, do qual podemos nos aproximar (o qual talvez não seja plenamente atingível e/ou não seja, ainda, totalmente claro para o agente). Uma das características do bem educado é justamente inclinar-se diante da verdade, seguir a conclusão de um argumento porque ela de fato se segue de boas (isto é, verdadeiras) premissas, não porque isso o agrada. É com esse sentimento que o bem educado aborda as questões éticas e sobre a boa vida, visando esclarecer o que há nela de real e 
verdadeiramente bom. $\mathrm{O}$ bem educado busca realizar essa vida plena, busca o que é o bom. O esclarecimento desse bom, desse ápice, dessa meta intuitivamente por ele buscada certamente lhe será útil. Entretanto, para o mal educado ou vicioso, provavelmente será um fardo incompreensível. Para escapar da dificuldade de considerar que também o bem educado adentra a investigação ética com seus sentimentos e convicções, portanto, não pretendo sugerir que ele consegue abstrair-se da discussão, considerando de modo neutro ou imparcial o assunto; não é por isso que ele é um "bom juiz" dos assuntos práticos, sejam eles mais pontuais, sejam mais gerais, mas porque tem um compromisso com a objetividade e com a verdade que ele encontra nesses assuntos.

A tarefa preliminar à investigação filosófica ética que a educação nos bons hábitos cumpre é permitir que o agente conceda valor intrínseco à atividade virtuosa, que ele julgue que a virtude é algo desejável e verdadeiramente bom, inclinando-o a buscar aquilo que realmente conta para uma vida feliz. Se é assim, ao considerar argumentos que visam esclarecer o valor e a natureza dessa vida, não lhe importa se ele já os considerou alguma vez e chegou sozinho às suas conclusões; não se apresenta como razão contra os argumentos e suas conclusões o fato de seus sentimentos não estarem plenamente (embora é certo que estejam parcialmente) de acordo com o que os argumentos estabelecem; não lhe será penoso (embora em alguma medida isso certamente tenha um custo) se ele tiver que abandonar certas práticas e hábitos já caros e em grande medida internalizados. O que lhe importa - o que ele busca - é que as mudanças ocorram sempre para o melhor e por boas razões, as quais ele reconhece como tais na teoria ética 
aristotélica. Ele crê, com efeito, que há um tipo de vida que é o melhor para o ser humano e as conclusões às quais ele chegar através da sua investigação serão por ele aceitas porque isso é o melhor. A aposta na existência de uma resposta certa para a questão "como devo viver?" qualifica o bem educado como alguém que seguirá com proveito a investigação, estando comprometido com a objetividade da sua empreitada.

\section{A BUSCA É PELA VERDADE, NÃO PELO QUE CONVÉM}

Parece, portanto, que aquele que foi educado nos maus hábitos não pode crer na existência de uma resposta única para todos à questão da boa vida, pois se assim fosse ele estaria comprometido com argumentos e suas conclusões. Ele precisa - ou quer - crer, apenas, na sua resposta. Como afirma Kraut,

Se ela [uma pessoa] se põe a estudar ética com a ideia fixa de que qualquer sacrifício que faça do seu poder, riqueza e status é uma perda do seu bem estar, ou se não encontra nada de atraente e prazeroso em agir bem em uma tarefa realizada em vista de outras pessoas, então seus ouvidos estarão fechados à sugestão de que há outras coisas que ela não conhece e que são não menos valiosas, talvez mesmo mais valiosas, do que aquilo que the parece ser bom. Sua concepção ética pode ser internamente consistente, mas falta-lhe o sopro da experiência ética e a objetividade intelectual que são necessárias para (...) chegar a uma prova genuína daquilo em que acredita (KRAUT 2009, 93) (grifos meus).

Isso significa que o mal educado - aquele que segue uma a uma as suas paixões - está comprometido com certo subjetivismo, ou melhor, com uma atitude subjetivista. Com esse termo, aqui, quero apenas designar o apego a valores e concepções simplesmente porque são nossos valores e concepções. Não quero dizer com isso que apegar-se aos nossos valores é ser "do mal", assim como não estou 
disposta a assumir que quem quer que se comprometa com a objetividade na ética é, apenas por isso, "do bem". Alguém que crê na objetividade dos seus valores pode tomálos ou tomar a teoria ética que os sustenta como régua para medir todas as pessoas e cortar quase que literalmente as cabeças daquelas que passam da medida. Da mesma forma, apegar-se às nossas concepções porque são nossas pode nos impedir de mudar de ideia, mas pode justamente por isso nos tornar sensíveis e tolerantes às concepções dos outros, permitindo compreender melhor por que também eles não mudam de ideia. $\mathrm{O}$ que eu quero é salientar que a busca pela virtude e pelo melhor é comprometer-se com a objetividade, e que a busca pelo que as paixões colocam a alguém, sem levar em conta se isso é ou não realmente bom, o afasta desse compromisso. "Qual a melhor vida para um ser humano?" não é a pergunta que guia as suas ações e o possível engajamento em uma discussão ética, mas "o que mais me agrada ou apraz?" ou "Isso está de acordo com o que eu penso?". Na medida em que o bem educado busca realizar a melhor vida possível, ele se engaja na investigação ética de modo comprometido com a verdade e com a ideia de que uma resposta é a correta para a questão "como devo viver?". A resposta a essa questão será bastante ampla e articulada em linhas gerais, mas, talvez justamente por isso, será necessária e necessariamente a mesma para todo ser humano enquanto tal ${ }^{15}$.

\footnotetext{
15 Um passo posterior seria verificar se a resposta de Aristóteles é dada realmente em linhas gerais ou se ele acaba por advogar em favor de uma concepção específica de boa vida, a qual teria entrado sorrateira e discretamente no argumento sem que nos déssemos conta (do que alguns comentadores acusam Aristóteles quando ele conclui que a vida perfeitamente feliz é a do filósofo e, em segundo lugar, a do político, não restando, aparentemente, felicidade para a vida dedicada às demais atividades; cf. LAWRENCE 2009, 43-44).
} 


\section{A MÁ EDUCAÇÃO E A AQUISIÇÃO DOS PRIMEIROS PRINCÍPIOS (ARCHAI) ÉTICOS}

Apenas algumas pessoas são capazes de seguir com proveito a investigação ética não porque a ética ela mesma tem um estatuto diferenciado - enquanto investigação ela se comporta como todo e qualquer conhecimento -, mas porque nem todas as pessoas dispõem de certos pressupostos, certo saber prévio para dar conta do que se apresenta. A ética aristotélica esclarece o que é o bem supremo para o ser humano, portanto, é válida, verdadeira e necessária para todo ser humano. No entanto, razões para agir, ainda que muito gerais, são razão para agir para alguém. O "agir" que está na pauta das considerações feitas por Aristóteles na EN certamente é amplo, direcional e mediado. Sendo assim, uma teoria que eu sigo acerca do que é bom precisa implicar uma reflexão que eu faço acerca do que é bom para mim. A teoria ética só levará à referida reflexão se o estudante já dispuser dos sentimentos minimamente educados. A teoria tem sentido em si; mas ela precisa fazer sentido para ele, apresentar-se como algo relevante e não imposto, arbitrário, gratuito ou até mesmo violento, como pode ser para as pessoas que sequer tiveram a experiência da atividade virtuosa como valiosa por ela mesma.

É como se Aristóteles afirmasse o seguinte: "Veja, apenas os virtuosos são felizes; estes que são bem educados, estão no caminho da virtude. Se você quiser ser feliz, é preciso mudar drasticamente de estratégia, trocar de time. Seguindo as suas paixões cegamente, meu caro, você não será feliz (embora ser virtuoso não seja garantia de felicidade, mas uma condição necessária e a principal 
condição).” Assim, não é o caso que Aristóteles restrinja sua teoria ética ou selecione a sua audiência; o caso é que a boa educação é necessária para "abrir os ouvidos" aos argumentos éticos. $\mathrm{O}$ imaturo, o que tende ao vício e o incontinente são excluídos não por preconceito ou elitismo de Aristóteles: de certa forma, eles mesmos se excluem, deliberadamente ou não. A ideia aqui é aquela já assinalada por Kraut: você pode argumentar com eles da melhor forma possível, mas eles não lhe darão ouvidos. $\mathrm{O}$ argumento pode ser bom, ter as mais firmes bases, mas eles ainda não conseguem - por serem jovens - ou não querem - por serem viciosos - ouvir, pois vivem do modo oposto ao afirmado e não são capazes de reconhecer no que dizemos boas razões para mudar de vida.

Uma outra maneira de abordar a restrição da audiência - da audiência, não da teoria ética - é levando em conta o vocabulário dos "primeiros princípios" (archai) presente no início da EN. Aristóteles não pretende, com sua investigação ética, informar ao estudante quais são esses princípios no sentido de proporcionar uma apreensão de algo com o que ele nunca teve contato; antes, pretende esclarecer ou tornar explícito algo que de maneira implícita ou vaga ele já conhece. $\mathrm{O}$ exercício filosófico é aquele da busca pelo esclarecimento das causas e princípios - no caso, das causas e princípios da boa vida. Se analisarmos com calma e sem alarde o assunto, veremos que a restrição da audiência bem educada se repete em todas as empreitadas filosóficas de Aristóteles. Na Física, é preciso ter experiência dos seres naturais; na Astronomia, observar atentamente os corpos celestes, na Biologia, observar o seres vivos etc. $\mathrm{O}$ que é comum a todas essas empreitadas é que é preciso, sempre, previamente aprender e apreender o objeto de 
estudo por outra via que a investigativa: o aluno precisa ter experiência do objeto que será estudado. Somente assim ele poderá investigar as suas causas, por já conhecê-las, ainda que parcialmente. É por essa razão que Kraut afirma que "toda investigação, não apenas a investigação ética, recusará dar crédito às opiniões daqueles que têm pouco contato com os fenômenos que estão sendo investigados. Não é exclusivo da teoria ética que ela não possa ser aceita por todos os seres humanos racionais" (KRAUT 2009, 94), embora seja válida para todos.

No caso da teoria ética, a apreensão do seu objeto se dá através da experiência na atividade virtuosa: não basta ser exposto a ela - como se alguém ao meu lado dissesse: "olha só, esta é uma ação virtuosa!” -; é preciso realizá-la. Repito: realizá-la e não simplesmente reproduzir de maneira mecânica ou desengajada movimentos ou atos que um virtuoso realizaria. $\mathrm{O}$ hábito ensinará para ele aquilo que a teoria ética virá explicitar e esclarecer depois: que e como essa é a parte mais importante da boa vida. Buscar as causas da bondade, do prazer oriundo da realização dessa atividade, obter esclarecimentos acerca do lugar, importância e abrangência da atividade virtuosa na sua vida: eis algo que a investigação na EN proporcionará para ele. Mas, para isso, ele precisa já realizar a atividade virtuosa: pouco ou nenhum sentido faz para alguém que jamais tocou um instrumento musical esclarecer a origem de suas técnicas e refletir sobre a importância na vida de tocar um instrumento.

\section{CONSIDERAÇÕES FINAIS}

Quero finalizar citando um trecho em que Kraut lembra os 
leitores da EN do projeto aristotélico ao desenvolvê-la. Tal trecho funciona como uma resposta às questões que coloquei aqui, no início deste texto. São elas: esse estudo não deveria oferecer argumentos que visassem orientar ou convencer os que estão no mau caminho a mudar de vida? A teoria ética não vem a ser uma espécie de pregação aos já convertidos, uma vez que os beneficiados por ela já "desejam e agem de acordo com um princípio racional"? Não seria necessário que a teoria moral se apoiasse em dados universais e inegáveis de todo ser humano, o que a autorizaria a se impor a todos de maneira indiscutivel, a despeito das suas disposições e experiências prévias? A isso respondo, com Kraut, que:

Seria um erro pensar que é uma falha de uma teoria ética que ela não ofereça argumentos sobre o bem e o mal que deveriam ser aceitos por qualquer pessoa pensante, baseando-se em proposições que aquela pessoa já aceita. Com efeito, isso seria uma falha se a única razão para buscar justificação fosse mudar as ideias de alguém que discorde disso. Porém, a justificação aristotélica, como notamos no início, não é uma tentativa de persuadir aqueles de quem discordamos ou transformar céticos éticos imaginários em boas pessoas. Ela é uma tentativa de sair de si mesmo e aprender com os outros, mas seu objetivo é alcançar a auto-segurança justificada, não o consenso (KRAUT 2009, 94).

Se o que afirmei aqui estiver correto, então parece haver um problema com algumas tentativas de ver o início da EN, em especial até e inclusive o argumento da função própria em I 7, como plausíveis e razoáveis porque formais e racionalmente irrecusáveis. Gavin Lawrence, por exemplo, afirma que alguém como Trasímaco concordaria com a conclusão do argumento da função própria ${ }^{16}$. Penso,

16 Cf. LAWRENCE 2009, 55. 
no entanto, que alguém como Trasímaco nem chegaria, na investigação, até lá. De fato, ele “torce o nariz" para uma versão muito semelhante do argumento presente no final do livro I da República ${ }^{17}$. Não basta considerar o que é ser um ser capaz de se dar regras ou um propósito específico para admitir, em primeiro lugar, a existência de um bem supremo para nós e, em segundo lugar, a ideia de que realizar esse bem é exercer bem ou em conformidade com a virtude a nossa racionalidade. Há um sentido normativo na atribuição de racionalidade e de virtude que, penso, alguém como Trasímaco não estaria disposto a admitir como existente ou como utilizado por ele. No entanto, é segundo esse sentido que dizemos que alguém age racionalmente ou age bem, significando com isso não (ou não apenas) que alguém faz o que faz usando a razão ou sendo eficiente (o que corresponderia a um modo descritivo de atribuir racionalidade e virtude), mas que o faz do bom modo ou do melhor modo possível, o que implica considerar critérios ou qualificações de algo como moralmente bom. ${ }^{18}$ Mas isso só pode ser reconhecido por alguém que já direciona a constituição do seu caráter na direção da virtude.

Abstract: This paper aims to show how and why the commitment to objectivity is a characteristic of the good student as described in Aristotle's Nicomachean Ethics. Therefore, it attempts to provide at least one justification for the Aristotelian requirement of good habits as a precondition to follow his ethical lessons. As will be seen, such habits are somehow responsible for engendering the commitment to objectivity. Engaging in virtuous activity provides students with experience in what is really living well and thus provides the proper perspective from which they will be able to correctly judge arguments concerning the good life for human beings.

17 Cf. 352d-354b.

18 A distinção entre os modos descritivo e normativo de atribuir racionalidade ou um "bem feito" a alguma atividade é apresentada por KORSGAARD 2004, 143-144. 
Keywords: Objectivity; Ethics; Aristotle; Moral Virtue.

\section{REFERÊNCIAS}

ARISTÓTELES. Ethica Nicomachea. L. Bywater. Oxford: Clarendon Press, 1894;

. The Nicomachean Ethics. ROSS, D. W. (trad.), Ackrill, J. L. e Urmson, J. O. (rev.). Oxford: Oxford University Press, 1998;

BOLZANI, R. "A retomada da tese de Trasímaco no segundo livro de A República" (no prelo);

- "Glauco, guardião do lógos". Dois Pontos, vol. 10, n⿳⺈ 2, out. 2013, pp. 11-32;

KRAUT, R. "Como justificar proposições éticas: o método de Aristóteles". Aristóteles: A Ética a Nicômaco. Kraut, R. (ed.). Trad. Alfredo Storck (et al.). Porto Alegre: Artmed, 2009, pp. 77-94;

. "Aristotle on Method and Moral Education". Method in Ancient Philosophy. Gentzler, J. (ed.). Oxford: Clarendon Press, 1998, pp. 271-290;

KORSGAARD, C. "Aristotle's Function Argument". The Constitution of Agency: essays on practical reason and moral psychology. Oxford: Oxford University Press, 2008, pp. 129-150;

LAWRENCE, G. "O bem humano e a função humana". Aristóteles: A Ética a Nicômaco. Porto Alegre: Artmed, 2009, 42-76;

PLATÃO. A República. Fundação Calouste Gulbenkian, 
Priscilla Tesch Spinelli

12를. ed., 2000;

WILLIAMS, B. Ethics and the Limits of Philosophy. London: Fontana, 1985. 